\title{
Cis-Dioxomolybdenum (VI) Complexes with N-donor Macrocyclic Ligands
}

\author{
Ramesh Kumar Gautam ${ }^{1}$ (D), Chandra Prakash Singh ${ }^{2}$ (D), Devendra Pratap Rao ${ }^{\text {1,* (D) }}$ \\ 1 Department of Chemistry, D.A-V. (P.G.) College, Kanpur-208001, U.P., India \\ 2 Department of Chemistry, D.B.S. College, Kanpur - 208006, U.P., India \\ * Correspondence: devendraprataprao@yahoo.com (D.P.R.);
}

Scopus Author ID 35119371500

Received: 14.03.2021; Revised: 10.04.2021; Accepted: 14.04.2021; Published: 27.04.2021

\begin{abstract}
The preparation of one monomeric $\left[\mathrm{MoO}_{2}(\mathrm{~L})\right](\mathrm{acac})_{2}$ having a Schiff base came by condensation of di-2-furanylethanedione with 2,3-diaminotoluene and 4 different complexes having formulation $\left[\mathrm{MoO}_{2}(\mathrm{ML})\right](\mathrm{acac})_{2}$, from the result of $\left[\mathrm{MoO}_{2}(\mathrm{~L})\right](\mathrm{acac})_{2}$ with 1,3-diketones will be described with this paper. The preparation of each of these five $\mathrm{MoO}_{2}$ (VI) complexes was symbolized by thermal studies, UV-Vis, IR, elemental analyses, NMR, and molar conductance. The coordination number of molybdenum metal will be six. All 5 complexes of $\mathrm{MoO}_{2}(\mathrm{VI})$ have a geometry of distorted octahedral arrangement. The octahedral arrangement of Mo-metal in prepared complexes is finished by 2 oxo $\mathrm{O}$-atoms and $4 \mathrm{~N}$-atoms from the synthesized ligand. All of the synthesized complexes demonstrated moderate action against S. aureus and S. typhi. The progression inside the antibacterial task being defined on the thought of chelation speculation.
\end{abstract}

Keywords: dioxomolybdenum(VI); di-2-furanylethanedione;1,3-diketones;macrocyclic complexes; Schiff base.

(C) 2021 by the authors. This article is an open-access article distributed under the terms and conditions of the Creative Commons Attribution (CC BY) license (https://creativecommons.org/licenses/by/4.0/).

\section{Introduction}

The macrocyclic complex is a cyclic complex that contains at least 9 atoms, including all heteroatoms. In such complexes, at least 3 donor atoms will be present. The discipline of the chemistry of macrocyclic complexes possesses experienced development amid the prior past hundred years [1-5]. Ligands containing $\mathrm{N}$-atom and Schiff bases and their complexes assumed a significant job in improving coordination chemistry. Several research papers have been published, ranging from physicochemical and biochemically pertinent be taught of metal complexes and driven extensive selection of applications [6-11]. Schiff-based compounds were applied as medicines and had worthwhile antifungal, antiviral, anti-inflammatory, and antitumor properties [12-20]. Metal ions catalyzed the transamination reactions via the production of transitional Schiff bases formulated with vitamin B6 [15].

Fascination with complexes of Schiff base in the bioinorganic field has directed at the purpose of such complexes in imparting manufactured models to the metal-containing positions in metalloproteins and enzymes [21]. Various Schiff bases have anticancer activity of that particular metal complex is greater in evaluation to the isolated ligand [22-24]. They endure durable catalytic fascination with various reactions in chemistry so when memory storage gizmos in consumer electronics [25-29]. 
Transition metal complexes with extreme denticity ligands have different configurations and coordination numbers [31]. Molybdenum can be adaptable due to its multiple oxidation states, ranging from -2 to +6 . In the same way, coordination numbers vary from 4 to 8 [32]. The capability to connect molybdenum complexes with ligands containing N, $\mathrm{O}$ - and $\mathrm{S}$-atoms induced growth of Mo Schiff base edifices, which are productive impetuses in homogeneous and heterogeneous reactions [33-39]. $\mathrm{MoO}_{2}$ (VI) complexes with multidentate ligands have super value in the theoretical and functional region predominantly for biological functions. $\mathrm{Mo}(\mathrm{VI})$ can be acquired as an effortless $\left[\mathrm{MoO}_{4}\right]^{2-}$ ion in an aqueous medium. $\left[\mathrm{MoO}_{4}\right]^{2-}$ ion can be based on the concentration and $\mathrm{pH}$ of the solution. The $\left[\mathrm{MoO}_{4}\right]^{2-}$ ion can perform as an oxygen transfer template [40-41]. Their oxygen transfer qualities play a negative role in the performing mechanism of molybdenum oxotransferase [42,43]. Several redox enzymes are present in a fully oxidized state. In such cases, their active sites consist of a cisdioxomolybdenum moiety [44-46].

In the second series of transition metals, entirely molybdenum is considered a biometal crucial for human, animal, and vegetation pathogenic microorganisms [47,48]. The coordination chemistry of $\mathrm{Mo}(\mathrm{VI})$ is of thriving interest for the present research because of their catalytic activities and biological properties [49-52]. Physiological functions of oxomolybdoenzymes are set up via molybdenum [53-55]. Di-2-furanylethanedione may be a versatile chelating agent. Di-2-furanylethanedione has two reactive carbonyl groups, which might be capable of undergoing Schiff base condensation with several di- and polyamines. Therefore, di-2-furanylethanedione has performed an essential function within the synthesis of macrocyclic ligands.

With on pinnacle of context, some dioxomolybdenum(VI) complexes with excessive denticity ligands can synthesize from the condensation of di-2-furanylethanedione with a diamine. The synthesized complex has the ability to undergoing cyclization with 1,3-diketones via the metal template impact. They can be prepared, characterized and their provisional structures are supported by molar conductivity, elemental analysis, electronic, infrared, and nuclear magnetic resonance spectroscopy.

Retaining because of the importance of $\mathrm{Mo}_{2}(\mathrm{VI})$ cations, a new sequence of dioxomolybdenum(VI) macrocyclic complexes were synthesized. Those dioxomolybdenum(VI) macrocyclic complexes with new chelate ligands derived from the condensation of di-2-furanylethanedione with 2,3-diaminotoluene successful in presenting process cyclization with 1,3-diketones through the metallic template impact have been synthesized. Herein, the synthesis and ascertaining structures based totally on molar conductivity, elemental analyses, electronic IR, NMR, and TGA/DTA are reported.

\section{Materials and Methods}

All chemicals utilized for the preparation of Schiff base (ligands) and complexes had been of reagent grade and utilized as obtained from business resources. Molybdenyl acetylacetonate, 2,3-diaminotoluene, di-2-furanylethanedione and 1,3-diketones (2,4pentanedione, 1-phenyl-1,3-butanedione, 4,4,4-trifluoro-1-(2-thienyl)-1,3-butanedione, and 1,3-diphenyl-1,3-propanedione) were obtained from Aldrich and utilized without similarly purging. 


\subsection{Analytical methods and physical measurements.}

Examinations of $\mathrm{C}, \mathrm{H}$ and $\mathrm{N}$ for the complexes were done at important CRF, NERIST, Nirjuli, Itanagar, Arunachal Pradesh, India by using CHN analyzer. Kjeldahl's method becomes used to assess nitrogen for the synthesized complexes. After the decay of the complex, molybdenum was assessed gravimetrically via standard technique [56]. Estimation of sulfur progressed toward becoming accomplished as barium sulfate [57]. The general method changed into utilized for deciding uncorrected melting factors with the assistance of sulfuric acid bath. The electronic absorption spectral computation (the UV-Visible spectra) of the complexes was recorded on Labinda-UV $3000^{+}$UV/VIS spectrophotometer inside the reaches $1100-220 \mathrm{~nm}$ by utilizing ethanol as solvent at UPTTI Kanpur, U.P., India. The infrared spectra of $\mathrm{MoO}_{2}$ (VI) complexes $\left(4000-400 \mathrm{~cm}^{-1}\right.$ ) had been recorded in $\mathrm{KBr}$ on Perkin-Elmer Spectrum model 10.03.06 spectrophotometers at IIT Kanpur. NMR spectra of $\mathrm{MoO}_{2}(\mathrm{VI})$ complexes were procured on JMM ECS-400 (JEOL) spectrometer with $400 \mathrm{MHz}$ for proton $\left({ }^{1} \mathrm{H}\right.$ NMR). Thermograph of the produced parent complex $\left[\mathrm{MoO}_{2}(\mathrm{~L})\right](\mathrm{acac})_{2}$ was done under nitrogen atmosphere in the temperature extend $50-600{ }^{0} \mathrm{C}$ at the heating rate $10{ }^{0} \mathrm{C} \mathrm{min}-1$ utilizing TG/DTA - Perkin Elmer, USA thermal analyzers.

2.2. In-situ synthesis of dioxomolybdenum(VI) complexes with ligands derived by condensation of di-2-furanylethanedione with 2,3-diaminotoluene with 1,3-diketones.

Schemes 1, 2and 3 display the synthesis way of $\left[\mathrm{MoO}_{2}(\mathrm{ML})\right](\mathrm{acac})_{2}$. An ethanolic solution of molybdenyl acetylacetonate $(2.5 \mathrm{mmol}, 0.81537 \mathrm{~g})$ was brought drop smart to a refluxing solution of di-2-furanylethanedione $(2.5 \mathrm{mmol}, 0.5570 \mathrm{~g})$ and 2,3-diaminotoluene (5 mmol, $0.61164 \mathrm{~g})$ in ethanol $(50 \mathrm{~mL})$ in $\mathrm{RB}$ flask. The resulting reaction mixture was slightly refluxed for $3 \mathrm{~h}$. The coloration of the solution becomes brown. The received solid product was filtered off, washed with ethanol, and isolated beneath in vacuo over silica gel. TLC method was employed for checking the purity of the prepared complex. The yield became $46 \%$ (type A).

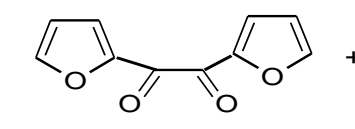

di-2-furanylethanedione

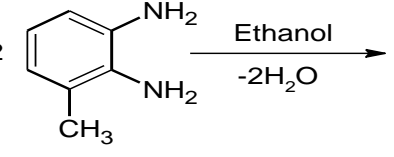

2,3 - diaminotoluene

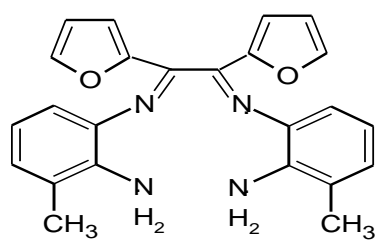

[L]

Scheme 1. Synthesis of Ligand (L).
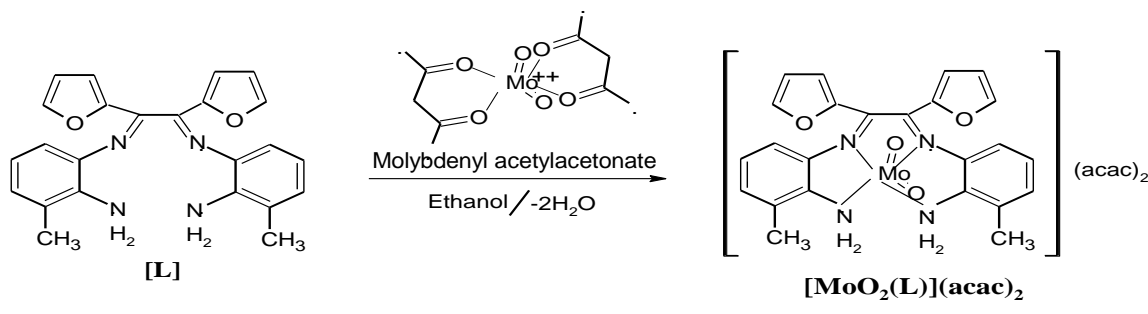

Type A

Scheme 2. Synthesis of $\left[\mathrm{MoO}_{2}(\mathrm{~L})\right](\mathrm{acac})_{2}$. 


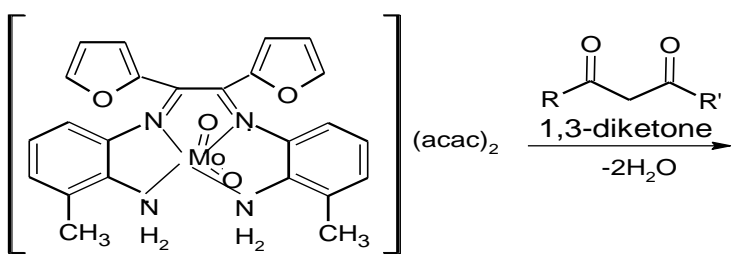

$\left[\mathrm{MoO}_{2}(\mathrm{~L})\right](\mathbf{a c a c})_{2}$

Type A

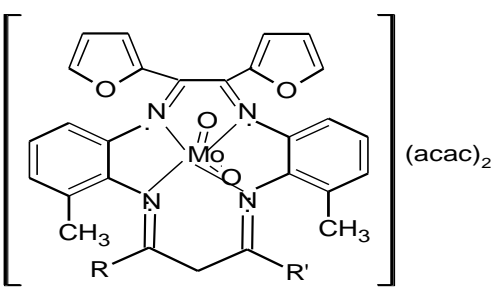

$\left[\mathrm{MoO}_{2}(\mathrm{ML})\right](\mathbf{a c a c})_{2}$

Type B

Scheme 3. Synthesis of $\left[\mathrm{MoO}_{2}(\mathrm{ML})\right](\mathrm{acac})_{2}$ where, $\mathrm{L}=$ difuranylethanedione+2,3-diaminotoluene; $\mathrm{ML}=$ macrocyclic ligands carried out from condensation of $\mathrm{L}$ with 1,3-diketones in presence of dioxomolybdenum(VI) cation.

Where, $\mathrm{L}=$ di-2-furanylethanedione +2 ,3-diaminotoluene; $\mathrm{ML}=$ macrocyclic ligands carried out from condensation of $\mathrm{L}$ with 1,3-diketones in presence of dioxmolybdenum(VI) cation.

Table 1. Physical and analytical data of the ligand and complexes.

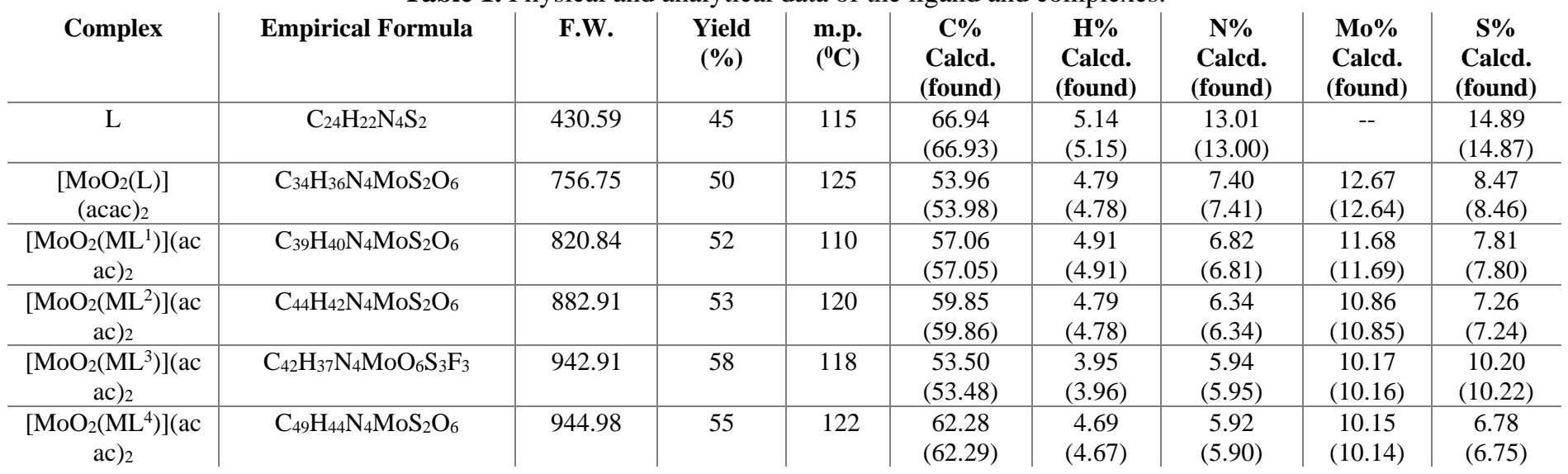

Table 1'. Description.

\begin{tabular}{|c|c|c|c|c|}
\hline For macrocyclic & $\mathbf{R}$ & R' & 1,3-diketone & Structure \\
\hline $\mathrm{ML}^{1}$ & $\mathrm{CH}_{3}$ & $\mathrm{CH}_{3}$ & 2,4-pentanedione & \\
\hline $\mathrm{ML}^{2}$ & $\mathrm{C}_{6} \mathrm{H}_{5}$ & $\mathrm{CH}_{3}$ & 1-phenyl-1,3-butanedione & \\
\hline $\mathrm{ML}^{3}$ & $\mathrm{C}_{4} \mathrm{H}_{3} \mathrm{~S}$ & $\mathrm{CF}_{3}$ & $\begin{array}{l}\text { 4,4,4-trifluoro-1-(2-thienyl)- } \\
\text { 1,3-butanedione }\end{array}$ & \\
\hline $\mathrm{ML}^{4}$ & $\mathrm{C}_{6} \mathrm{H}_{5}$ & $\mathrm{C}_{6} \mathrm{H}_{5}$ & $\begin{array}{l}\text { 1,3-diphenyl-1,3- } \\
\text { propanedione }\end{array}$ & \\
\hline
\end{tabular}

$\mathrm{L}=$ ligand derived via condensation of di-2-furanylethanedione with 2,3-diaminotoluene (1:2);

$\mathrm{ML}^{1}=$ macrocyclic ligand derived via condensation of ligand (L) with 1,3-diketone-2,4-pentanedione ;

$\mathrm{ML}^{2}=$ macrocyclic ligand derived via condensation of ligand (L) with 1,3-diketone-1-phenyl-1,3-butanedione;

$\mathrm{ML}^{3}=$ macrocyclic ligand derived via condensation of ligand (L) with 1,3-diketone-4,4,4-trifluoro-1-(2-thienyl)1,3-butanedione;

$\mathrm{ML}^{4}=$ macrocyclic ligand derived via condensation of ligand (L) with 1,3-diketone-1,3-diphenyl-1,3propanedione.

The solution of Kind A suspended in ethyl alcohol uniformly reacted for three $\mathrm{h}$ with 1,3-diketones viz. 2,4-pentanedione, 1-phenyl-1,3-butanedione, 4,4,4-trifluoro-1-(2-thienyl)1,3-butanedione or 1,3-diphenyl-1,3-propanedione (1:1) to gain macrocyclic dirty yellow solid stable products (type B). The purity of the macrocyclic complexes turns into checked by way of TLC. 
Elemental analyses (Table 1) of the complexes revealed 1:1 metal to ligand stoichiometry.

\subsection{Antibacterial activity assay.}

The antibacterial interest of the synthesized dioxomolybdenum(VI) complexes was examined in vitro against four bacterial strains, i.e., Staphylococcus aureus, Bacillus subtilis, Enterobacter aerogene, and Salmonella typhi, utilizing a cup and agar-well diffusion method [58-60]. Doxycycline drug changed into used as the identical general antibacterial agent. Wells having dimensions of $6 \mathrm{~mm}$ in diameter were dug inside the agar media with the help of a metallic borer. The density of each bacterial suspension in each well turned into adjusted to 3 $\times 10^{5}$ colony-forming units $(\mathrm{CFU}) \mathrm{mL}^{-1}$. The standardized suspensions were expanded on the surface of the agar. The produced complexes have been dissolved in $1 \%$ DMSO, and the concentration of the examined sample was $300 \mu \mathrm{g} \mathrm{mL}^{-1}$. The examined samples were added within the corresponding wells. The rest wells were packed with DMSO and antibacterial medium doxycycline $(0.05 \%)$. Growth inhibition becomes tested after $30 \mathrm{~h}$ incubation at 35 ${ }^{\circ} \mathrm{C}$.

\section{Results and Discussion}

\subsection{Infrared spectra.}

The dioxomolybdeum(VI) had been prepared via the use of an in-situ approach to reflux the reaction mixture of di-2-furanylethanedione 2,3-diaminotoluene, and molybdenyl acetylacetonate in 1:2:1 molar ratio in aqueous ethanol, which results in macrocyclic complexes in the scheme. Remarkable infrared spectral bands of the isolated ligand and the $\mathrm{MoO}_{2}$ (VI) complexes and their provisional assignments are given in table 2 . The bonding of $\mathrm{N}$-atoms of groups azomethine to the molybdenum in all macrocyclic complexes was evidenced with the aid of using the move of $v_{\mathrm{C}=\mathrm{N}}$ to lower frequencies [61-64]. The spectral bands place $1604-1645 \mathrm{~cm}^{-1}$ arecoupled to $>\mathrm{C}=\mathrm{N}$ absorption, which usually seems at $1665 \mathrm{~cm}^{-}$ ${ }^{1}$ in isolated ligands [61-63]. The new band at around 508-591 $\mathrm{cm}^{-1}$ may be assigned to $v_{\mathrm{Mo}-\mathrm{N}}$ vibration [65], i.e., not present in free ligands. The bonding of both keto groups of di-2furanylethanedione via carbonyl oxygen with diamines becomes supported via the presence of $>\mathrm{C}=\mathrm{N}$ band and the absence of the $>\mathrm{C}=\mathrm{O}$ band around $1710 \mathrm{~cm}^{-1}[66,67]$. Infrared spectra of the isolated ligand and its complexes of dioxomolybdeum(VI) are complex because of the appearance of diverse ring vibrations and C-H vibrations. A wideband targeted at $3433 \mathrm{~cm}^{-1}$

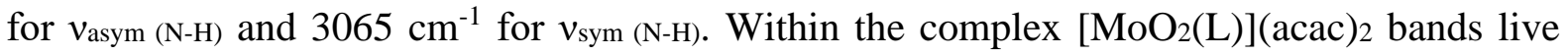
unchanged however absent in complex $\left[\mathrm{MoO}_{2}(\mathrm{ML})\right](\mathrm{acac})_{2}$ because this implies nonparticipation of the NH group in the bonding [68]. The dioxomolybdenum(VI) complexes create a cis-dioxo group preferentially because of the d-orbital for bonding. The dioxomolybdenum(VI) complexes revealed two $\mathrm{Mo}=\mathrm{O}$ stretching bands at $893-910 \mathrm{~cm}^{-1}$ and 964-981 $\mathrm{cm}^{-1}$ due to asymmetric and symmetric stretching vibrations of the $c i s-\left[\mathrm{MoO}_{2}\right]^{2+}$ moiety in $\mathrm{C}_{2} \mathrm{v}$ symmetry [69]. Those two infrared spectral bands are allocated tovasym $(\mathrm{O}=\mathrm{Mo}=\mathrm{O})$ and $v_{\mathrm{sym}}(\mathrm{O}=\mathrm{Mo}=\mathrm{O})$ vibrations, respectively [69-76]. $v_{\text {asym }}(\mathrm{O}=\mathrm{Mo}=\mathrm{O})$ vibrations are lower than ones of $v_{\mathrm{sym}(\mathrm{O}=\mathrm{Mo}=0)}[77,78]$. The presence of acetylacetonate group found in the outer coordination sphere is affirmed using the bands performing around $1552-1569 \mathrm{~cm}^{-1}$, and $1467-1480 \mathrm{~cm}^{-1}$ are appointed to $v_{\mathrm{C}=\mathrm{O}}$ and $v_{\mathrm{C}=\mathrm{C}}$ vibrations [79]. Infrared spectral bands of the macrocyclic 
complexes exhibit unequal fashion of spectral bands. The asymmetrical and symmetrical N-H stretching vibrations of terminal amino groups disappear because of the binding of those amino groups with a carbonyl group of 1,3-diketones in cyclization methods $[79,80]$.

Table 2. IR spectral bands $\left(v / \mathrm{cm}^{-1}\right)$ of ligand and dioxomolybdenum complexes. All spectra had been recorded using $\mathrm{KBr}$ within the variety $4000-400 \mathrm{~cm}^{-1}$.

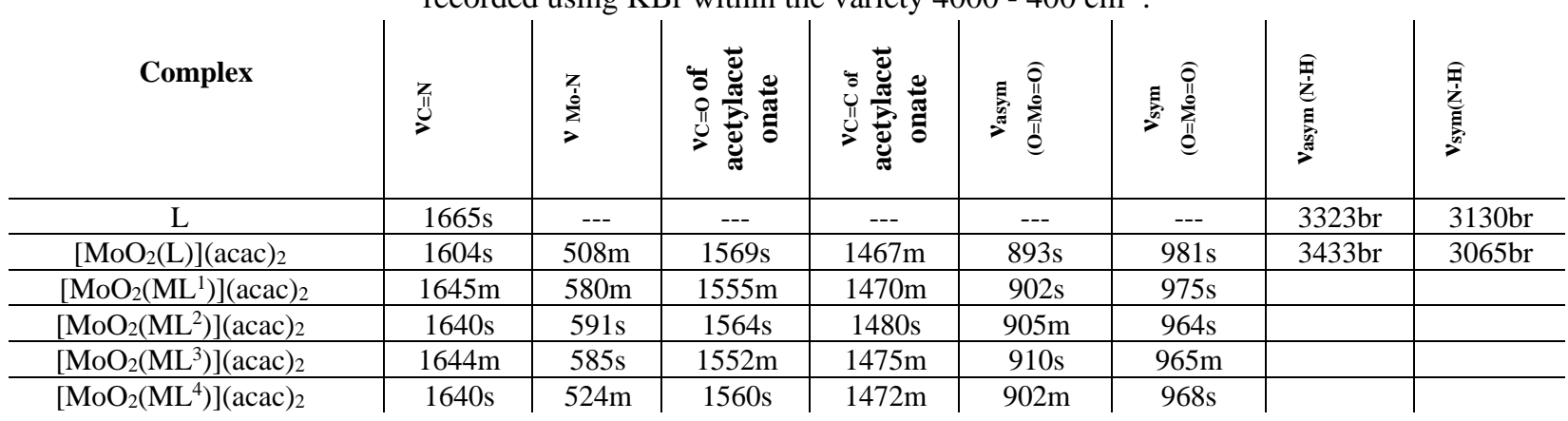

\section{2. ${ }^{1} H$ NMR spectra.}

Spectra ${ }^{1} \mathrm{H}$ NMR of ligand and all prepared $\mathrm{MoO}_{2}(\mathrm{VI})$ complexes were executed in DMSO-D $6 .{ }^{1} \mathrm{H}$ NMR spectrum of produced free ligand proposes signal because of $\mathrm{NH}_{2}$ at $\delta$ (10.20) which is additionally present in $\left[\mathrm{MoO}_{2}(\mathrm{~L})\right](\mathrm{acac})_{2}$ at $\delta(10.12)$ yet missing in various four macrocyclic complexes $\left[\mathrm{MoO}_{2}(\mathrm{ML})\right](\mathrm{acac})_{2}$ which recommend the cyclization by $1,3-$ diketones. The ten protons present as multiplets inside the range $\delta(7.06-7.84)$ for the isolated ligand and molybdenum complexes. The protons of the aromatic ring appeared by peaks about $\delta$ (7.26). ${ }^{1} \mathrm{H}$ NMR spectrum about $\delta(3.29-3.82)$ allotted to the $\mathrm{CH}_{2} \mathrm{~N}$ fragment. The appearance of these chemical shifts might directly result from the arrangement of two types of azomethine that is engaged in the preparation of the macrocyclic complex. The sharp singlet signal situated at $\delta$ (2.47) might be because of the water present in DMSO-D6 sample used.

Table 3. ${ }^{1} \mathrm{HNMR}$ Spectral Data of prepared ligand and dioxomolybdenum complexes (in $\delta \mathrm{ppm}$ ).

\begin{tabular}{c|c|c|c|c} 
Complex & HC-Ar & N-H & C-H3 & C-H \\
\hline $\mathrm{L}$ & $7.1210 \mathrm{H}$ & $10.204 \mathrm{H}$ & -- & -- \\
\hline$\left[\mathrm{MoO}_{2}(\mathrm{~L})\right](\mathrm{acac})_{2}$ & $7.7410 \mathrm{H}$ & $10.124 \mathrm{H}$ & $2.4612 \mathrm{H}$ & $5.712 \mathrm{H}$ \\
\hline$\left[\mathrm{MoO}_{2}\left(\mathrm{ML}^{1}\right)\right](\mathrm{acac})_{2}$ & $7.4210 \mathrm{H}$ & -- & $2.6912 \mathrm{H}$ & $5.582 \mathrm{H}$ \\
\hline$\left[\mathrm{MoO}_{2}\left(\mathrm{ML}^{2}\right)\right](\mathrm{acac})_{2}$ & $7.0610 \mathrm{H}$ & -- & $2.4512 \mathrm{H}$ & $5.702 \mathrm{H}$ \\
\hline$\left[\mathrm{MoO}_{2}\left(\mathrm{ML}^{3}\right)\right](\mathrm{acac})_{2}$ & $7.8410 \mathrm{H}$ & -- & $2.7012 \mathrm{H}$ & $5.522 \mathrm{H}$ \\
\hline$\left[\mathrm{MoO}_{2}\left(\mathrm{ML}^{4}\right)\right](\mathrm{acac})_{2}$ & $7.1510 \mathrm{H}$ & -- & $2.4912 \mathrm{H}$ & $5.582 \mathrm{H}$
\end{tabular}

\subsection{UV - Visible spectra.}

The Ultraviolet-Vis spectra of tetradentate tetraaza ligand and the dixomolybdenum(VI) complexes had been recorded in ethanol and those spectral bands are measured consistent with the suggested strength energy level scheme [81-83]. The spectra of the dixomolybdenum(VI) complexes with tetradentate ligand are comparable, thereby suggesting a widespread structure for all. In view that Mo(VI) ion has no d- electron, the absorption bands of pure d-d origins do now not appear to be expected to appear. The bands for all complexes may additionally perhaps be appointed as charge transfer transition from nitrogen orbital to a molybdenum metal d-orbital $[\mathrm{N}(\pi) \rightarrow d(\mathrm{Mo})]$. The Ultraviolet - Vis spectra are homogeneous to rest complexes of dioxomolybdenum(VI) having nitrogen donor atoms. The Ultraviolet - Vis spectra of those complexes are distinguished by strong absorption bands within the UV region at $\approx 292 \mathrm{~nm}$ and at $\approx 311 \mathrm{~nm}$ appear to be due to intraligand transition 
and $\mathrm{n} \rightarrow \pi^{*} / \pi \rightarrow \pi^{*}$ transitions. A fairly intense band that appeared in the vicinity $\approx 380 \mathrm{~nm}$ - $395 \mathrm{~nm}$ is attributed to $\mathrm{N}(\pi) \rightarrow d(\mathrm{Mo})$. The band due to the transition ${ }^{2} B_{2} \rightarrow{ }^{2} A_{1}\left(d_{x y} \rightarrow d_{x 2-y 2}\right)$ is perhaps covert through the above bands and ought to be appointed for $\mathrm{L} \rightarrow \mathrm{M}$ charge-transfer transition among the lowest unoccupied molybdenum d-orbital and highest occupied ligand molecular orbital [84-86]. Ballhausen - Gray energy level diagram has supplied energy level scheme for these complexes. The electronic spectra represent a distorted octahedral configuration for all the complexes [87].

The dioxomolybdenum(VI) complexes are diamagnetic, as pointless to mention for $\mathrm{d}^{0}$ configuration. Since there is no electron present in the d-orbital, no d-d transitions are decided for those complexes. The molar conductivity $(\Lambda \mathrm{M})$ values for all dioxomolybdenum(VI) complexes in DMF at ca. $10^{-3} \mathrm{M}$ endorse 1:1 sort electrolytes. The molar conductance values of those complexes lie between the ranges of $100-115 \Omega^{-1} \mathrm{~cm}^{2} \mathrm{~mol}^{-1}$. In final, the on top molar conductance values aid the tentative structures of dioxomolybdenum(VI) complexes of the type (I) and macrocyclic complexes of type (II) as shown in the schemes.

\subsection{Thermogravimetric analyses.}

The thermogravimetric investigation of $\left[\mathrm{MoO}_{2}(\mathrm{~L})\right](\mathrm{acac})_{2}$ complex has been governed in the temperature range $50-600{ }^{\circ} \mathrm{C}$ with a $10{ }^{\circ} \mathrm{C} \mathrm{min}-1$ temperature in-between. No transparent decomposition was remarked beneath $145{ }^{\circ} \mathrm{C}$ (Figure 1). The thermograph of the $\left[\mathrm{MoO}_{2}(\mathrm{~L})\right](\mathrm{acac})_{2}$ complex is shown in Figure 1. The $\left[\mathrm{MoO}_{2}(\mathrm{~L})\right](\mathrm{acac})_{2}$ complex undergoes decay in two levels: (a) first degree of decay $\left(145-250{ }^{\circ} \mathrm{C}\right.$ ) is because of the loss of ligand (mass loss obs. $45 \%$, calcd. $48 \%$ ) (b) in the second degree, the second successive weight loss of at raised temperature $\left(300-450{ }^{\circ} \mathrm{C}\right)$ giving a mass loss over $42 \%$ against calculated mass loss of $48 \%$.

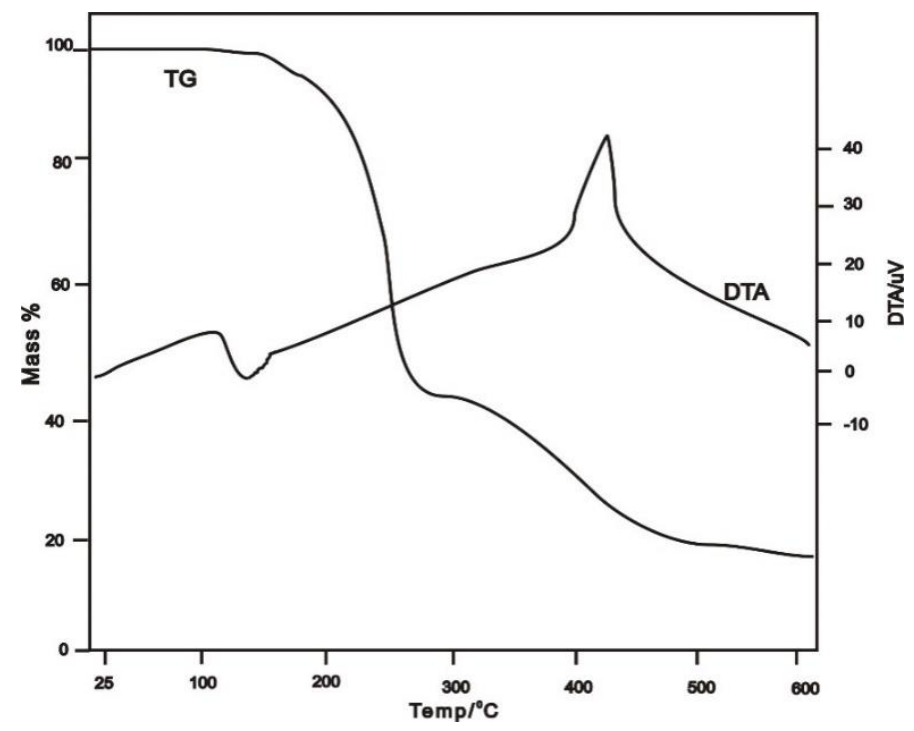

Figure 1. TG and DTA thermographs of $\left[\mathrm{MoO}_{2}(\mathrm{~L})\right](\mathrm{acac})_{2}$

At final, a residue obtained generally compares to $\mathrm{MoO}_{3}$ (obs. residual mass $=14.50$ $\%$, calcd. $=15.75 \%$ ) were left after $450{ }^{\circ} \mathrm{C}$. Two vertexes had been gotten in the DTA curve. The first vertex is endothermic decay due to the melting of the complex $\left(145^{\circ} \mathrm{C}\right)$. The second vertex is because of the exothermic effect. Close to this exothermic vertex in the DTA curve, an exothermic hump was also observed at $435^{\circ} \mathrm{C}$, which may also be due to the exothermic decay of the leftover mass in the second step. 


\subsection{Antibacterial activity.}

The consequences of the antimicrobial activity of the prepared dioxomolybdenum(VI) complexes are given in Table 3. The synthesized dioxomolybdenum(VI) complexes had been attempted towards Staphylococcus aureus, Bacillus subtilis, Enterobacter aerogenes, and Salmonella typhi. The improvement in the antibacterial interest of dioxomolybdenum(VI) complexes can be clarified on the idea of the chelation hypothesis $[79,80]$. The reference material is doxycycline remedy. Nearly all the complexes specified low to modest activity towards S. aureus and S. typhi.

Table 4. Antibacterial activities ofmacrocyclic complexes of dioxomolybdenum(VI).

\begin{tabular}{c|c|c|c|c|c} 
Complex & $\begin{array}{c}\text { Staphylococcus } \\
\text { aureus }\end{array}$ & $\begin{array}{c}\text { Enterobacter } \\
\text { aerogenes }\end{array}$ & $\begin{array}{c}\text { Salmonella } \\
\text { typhi }\end{array}$ & $\begin{array}{c}\text { Bacillus } \\
\text { subtilis }\end{array}$ & Doxycycline \\
\hline$[\mathrm{MoO} 2(\mathrm{~L})](\mathrm{acac}) 2$ & 17 & 17 & 19 & 20 & 26 \\
\hline$[\mathrm{MoO} 2(\mathrm{ML} 1)](\mathrm{acac}) 2$ & 14 & 20 & 17 & 22 & 23 \\
\hline$[\mathrm{MoO} 2(\mathrm{ML} 2)](\mathrm{acac}) 2$ & 14 & 17 & 16 & 20 & 24 \\
\hline$[\mathrm{MoO} 2(\mathrm{ML} 3)](\mathrm{acac}) 2$ & 15 & 19 & 19 & -- & 25 \\
\hline$[\mathrm{MoO} 2(\mathrm{ML} 4)](\mathrm{acac}) 2$ & 17 & 19 & -- & 22 & 25
\end{tabular}

\section{Conclusions}

As the crystals of complexes were not isolated, we cannot put forward the crystal structures of the respective complexes. From the above elemental and spectral studies, we may also advise that all the complexes synthesized can be represented as $\left[\mathrm{MoO}_{2}(\mathrm{~L})\right](\mathrm{acac})_{2}$ and $\left[\mathrm{MoO}_{2}\left(\mathrm{ML}^{1}\right)\right](\mathrm{acac})_{2}$. The antibacterial activity has been carried out on these complexes, which screen that the complexes are biologically active. The present study manifest primary synthetic paths to get new dioxomolybdenum(VI) with Schiff base. The applied spectroscopic methods have affirmed the Schiff base condensation of di-2-furanylethanedione, a flexible chelating agent with two responsive carbonyl groups with diamines, and their cyclizations 1,3-diketones present process formation of macrocyclic products to assure managed geometry around $\mathrm{MoO}_{2}$ (VI) center. The shape around Mo is distorted octahedral geometry. The kinetic template impact of dioxomolybdenum(VI) cation assumes a considerable function in the condensation of Schiff base using di-2-furanylethanedione and diamines in ethanol medium. Synthesized Schiff bases behave as tetradentate ligands by binding to the metal ion along with the azomethine nitrogen atoms. The existence of one metal ion per ligand molecule is declared by analytical data. The mononuclear six coordination of all the prepared cisdioxomolybdenum(VI) complexes and the six-coordinate distorted octahedral shape have been suggested for these complexes.

\section{Funding}

Any agency did not fund this research.

\section{Acknowledgments}

The authors may want to thank the Secretary, Board of Management, D.A-V. P.G. College, Kanpur, U.P., India for accommodating laboratory facilities to look at work. Analytical facilities supplied by IIT Kanpur and UPTTI Kanpur India are fortuitously identified. 


\section{Conflicts of Interest}

The authors declare no conflict of interest.

\section{References}

1. Healy, M.D.S.; Rest, A.J. Template reactions. Adv. Inorg. Chem. Radiochem. 1978, 21, 1-40. https://doi.org/10.1016/S0065-2792(08)60277-0.

2. Sergienko, V.S.; Abramenko, V.L.; Gorbunova, Y.E. Dioxomolybdenum (VI) Complexes with R1Substituted SalicylideneAllylimines ( $\mathrm{Hl} \mathrm{n}$ ): Synthesis and Structure. Crystal Structure of [MoO 2 (L 1) 2](R 1= H). Russ. J. Inorg. Chem. 2018, 63, 28-33. https://doi.org/10.1134/S003602361801014X.

3. Melson, G.A. Coordination Chemistry of Macrocyclic Compounds, Plenum Press: NY, 1979.

4. Lindoy L.F.; Busch, D.H. Preparative Inorganic Reactions, 1971, 6, 1.

5. Lindoy, L.F.; Busch, D.H. Metal ion controlled syntheses of novel five-coordinate zinc and cadmium complexes containing a helical coordination geometry and their template reaction to form complexes of a pentadentate macrocyclic ligand. Inorg. Chem. 1974, 13, 2494-2498. https://doi.org/10.1021/ic50140a037.

6. Luo, X.F.; Hu, X.; Zhao, X.Y.; Goh, S.H.; Li, X.D. Miscibility and interactions in blends and complexes of poly(4-methyl-5-vinylthiazole) with proton-donating polymers, Polymer 2003, 44, 52855291.https://doi.org/10.1016/S0032-3861(03)00578-0.

7. Murthy, A.S.N.; Reddy, A.R. Electronic absorption spectroscopic studies of enolimine-ketoamine equilibria in Schiff bases. J. Chem. Sci. 1981, 90, 519-526. https://www.ias.ac.in/article/fulltext/jcsc/090/06/0519-0526.

8. Razakantoanina, V.; Phung, N.K.P.; Jaureguiberry, G. Antimalarial activity of new gossypol derivatives, Parasitol. Res. 2000, 86,665-668. https://doi.org/10.1007/pl00008549.

9. Royer, R.E.; Deck, L.M.; Vander T.J.; Jagtm, Synthesis and anti-HIV activity of 1,1'-dideoxygossypol and related compounds, J. Med. Chem. 1995, 38, 2427-2432. https://doi.org/10.1021/jm00013a018.

10. Flack, M.R.; Pyle, R. G.; Mullen, N.M. Oral gossypol in the treatment of metastatic adrenal cancer. J. Clin. Endocrinol. Metab. 1993, 76, 1019-1024. https://doi.org/10.1210/jcem.76.4.8473376.

11. Baumgrass, R.; Weiwad, M.; Erdmann, F. Reversible inhibition of calcineurin by the polyphenolic aldehyde, gossypol, J. Biol. Chem. 2001, 276, 47914-47921. https://doi.org/10.1074/jbc.m103273200.

12. Eemis, E.; Durmus, K. Novel thiophene-benzothiazole derivative azomethine and amine compounds: Microwave assisted synthesis, spectroscopic characterization, solvent effects on UV-Vis absorption and DFT. J. Mol. Struct. 2020, 1217, 128354. https://doi.org/10.1016/j.molstruc.2020.128354.

13. Raman, N.; Sakthivel, A.; Rajasekaran K. Synthesis and spectral characterization of antifungal sensitive Schiff base transition metal complexes. Mycobiology 2007, 35, 150-153. https://doi.org/10.4489/MYCO.2007.35.3.150.

14. Creaven, B.S.; Czeglédi, E.; Devereux, M.; Enyedy, E.A.; Kia, A.F.A; Karcz, D.;Kellett, A.; McClean, S.; Nagy, N.V.; Noble, A.; Rockenbauer, A.;Szabó-Plánka, T.; Walshab, M. Biological activity and coordination modes of copper(II) complexes of Schiff base-derived coumarin ligands. Dalton Trans. 2010, 39, 1085410865. https://doi.org/10.1039/c0dt00068j.

15. Doctor, V.M.; Oro, J. Mechanism of non-enzymatic transition reaction between histidine and alphaoxoyglutaric acid. Biochem. J. 1969, 112,691-697. https://doi.org/10.1042/bj1120691.

16. El-Gammal, O.A.; El-Reash, G.M.A.; Goama, H.E. Mononuclear Cr(III), Mn (II), and Fe(III) complexes derived from new ONO symmetrical flexible hydrazone: synthesis, spectral characterization, optical band gap and DFT computational study. Lett. Appl. NanoBioScience 2019, 8, 743-753. https://doi.org/10.33263/LIANBS84.743753.

17. Rao, D.P.; Yadav, H.S.; Singh, C.P. Molybdenum(VI) complexes with Schiff base containing N-hetero atom. Lett. Appl. NanoBioScience 2021, 10(1), 1815-1824. https://doi.org/10.33263/LIANBS101.18161824.

18. Bharti, S.K.; Patel, S.K.; Nath, G.; Tilak, R.; Singh, S.K. Synthesis, characterization, DNA cleavage and in vitro antimicrobial activities of copper(II) complexes of Schiff bases containing a 2,4-disubstituted thiazole. Transit. Met. Chem. 2010, 35, 917-925. https://doi.org/10.1007/s11243-010-9412-8.

19. Manjunatha, M.; Naik, V. H.; Kulkarni, A.D.; Patil, S.A. DNA cleavage, antimicrobial, anti-inflammatory anthelmintic activities, and spectroscopic studies of $\mathrm{Co}(\mathrm{II}), \mathrm{Ni}(\mathrm{II})$, and $\mathrm{Cu}(\mathrm{II})$ complexes of biologically potential coumarin Schiff bases. J. Coord. Chem. 2011, 64, 4264-4275. https://doi.org/10.1080/00958972.2011.621082. 
20. Amer, S.; El-Wakiel, N.; El-Ghamry, H. Synthesis, spectral, antitumor and antimicrobial studies on $\mathrm{Cu}(\mathrm{II})$ complexes of purine and triazole Schiff base derivatives. J. Mol. Struct. 2013, 1049, 326-335. https://doi.org/10.1016/j.molstruc.2013.06.059.

21. Ohashi, M.; Koshiyama, T.; Veno, T.; Yanase, M.; Fujii, H.; Watanabe, Y. Preparation of artificial metalloenzymes by insertion of Chromium(III) Schiff base complexes in to apomyoglobin mutants. Angew. Chem. Int. Ed. 2003, 42, 1005-1008. https://doi.org/10.1002/anie.200390256.

22. Shiju, C.; Arish, D.; Kumaresan, S. Novel water soluble Schiff base metal complexes: Synthesis, characterization, antimicrobial-, DNA cleavage, and anticancer activity. J. Mol. Struct. 2020, 1221, 128770. https://doi.org/10.1016/j.molstruc.2020.128770.

23. Satheeshkumar, R.; Wu, J.; Chandrasekaran, R.; Revathi, K.; Sparkes, H.A.; Wang, W.L. Synthesis of 2aminobenzophenone-based Schiff base Pd(II) complexes: Investigation on crystal structure, biological behavior of DNA/protein-binding, molecular docking, and in vitro anticancer activities. Appl. Organomet. Chem. 2020, 34(10), e5856. https://doi.org/10.1002/aoc.5856.

24. Mohamed Shaker S. Adam.; Mohamed S. Mohamed Ahmed.; Omar M. El-Hady.; Saad Shaaban. Bisdioxomolybdenum (VI) oxalyldihydrazone complexes: Synthesis, characterization, DFT studies, catalytic epoxidation potential, molecular modeling and biological evaluations. Appl. Organomet. Chem. 2020, 34(5), e5573. https://doi.org/10.1002/aoc.5573.

25. Cozzi, P.G. Metal-Salen Schiff base complexes in catalysis: practicalaspects. Chem. Soc. Rev. 2004; 33, 410421. https://doi.org/10.1039/b307853c.

26. Singh, R.K.; Kukrety, A.; Saxena, R.C.; Thakre, G.D.; Atray, N.; Ray, S.S. Novel triazine Schiff base-based cationic gemini surfactants: Synthesis and their evaluation as Antiwear, antifriction, and anticorrosive additives in polyol. Ind. Eng. Chem. Res. 2016, 55, 2520-2526. https://doi.org/10.1021/acs.iecr.5b04242.

27. Karman, M.; Romanowski, G. Cis-dioxidomolybdenum(VI) complexes with chiral tetradentate Schiff bases: Synthesis, spectroscopic characterization and catalytic activity in sulfoxidation and epoxidation. Inorg. Chim. Acta. 2020, 511, 119832. https://doi.org/10.1016/j.ica.2020.119832.

28. Shukla, S.N.; Gaur, P.; Bagri, S.S.; Mehrotra, R..; Chaurasia B., Raidas, M.L. Pd(II) complexes with ONN pincer ligand: Tailored synthesis, characterization, DFT, and catalytic activity toward the Suzuki-Miyaura reaction. J. Mol. Struct. 2021, 1225, 129071. https://doi.org/10.1016/j.molstruc.2020.129071.

29. Abuzeid, H.R.; EL-Mahdy A.F.M.; Kuo, S.W. Covalent organic frameworks: Design principles, synthetic strategies, and diverse applications. Giant 2021, 6, 100054.https://doi.org/10.1016/j.giant.2021.100054.

30. Yadava, H.D.S.; Sengupta, S.K; Tripathi, S.C. Syntheses and spectroscopic studies on dioxouranium(VI), oxovanadium(IV) and oxozirconium(IV) complexes with tetradentate macrocyclic ligands. Inorg. Chim. Acta 1987, 128, 1-6. https://doi.org/10.1016/S0020-1693(00)84685-X.

31. Sergienko, V.S.; Abramenko, V.L.; Surazhskaya, M.D. Intracomplex dioxomolybdenum (VI) compounds with alcoholimines of aromatic o-Hydroxyaldehydes. Crystal structure of 2-hydroxynaphthylidene monoethanolimine $\left(\mathrm{H}_{2} \mathrm{~L}\right)$ and solvated complex $\left[\mathrm{MoO}_{2}(\mathrm{~L}) \cdot \mathrm{C}_{5} \mathrm{H}_{5} \mathrm{~N}\right]$. Russ. J. Inorg. Chem. 2020, 65, 495501. https://doi.org/10.1134/S0036023620040166.

32. Crans, D.C. Fifteen years of dancing with vanadium. Pure Appl. Chem. 2005. 77, 14071527.http://dx.doi.org/10.1351/pac200577091497.

33. Bagherzadeh, M.; Amini, M.; Parastar, H. Synthesis, X-ray structure and oxidation catalysis of a oxidoperoxidomolybdenum(VI) complex with a tridentate Schiff base ligand. Inorg. Chem. Commun. 2012, 20, 86-89. https://doi.org/10.1016/j.inoche.2012.02.023.

34. Moradi-Shoeili, Z.; Zare.; M.; Bagherzadeh, M.; Kubicki, M.; Boghaei, D.M. Preparation and structure of zinc complexes containing pincer ligands and their application for Knoevenagel condensation in water. $J$. Coord. Chem. 2015, 68, 548-559. https://doi.org/10.1080/00958972.2014.978308.

35. Bagherzadeh, M.; Amini, M.; Parastar, H. Synthesis, X-ray structure and oxidation catalysis of a oxidoperoxidomolybdenum(VI) complex with a tridentate Schiff base ligand. Inorg. Chem. Commun. 2012, 20, 86-89. https://doi.org/10.1016/j.inoche.2012.02.023.

36. Aziz, A.A.A. Synthesis, spectroscopic characterization, thermal studies, catalytic epoxidation and biological activity of chromium and molybdenum hexacarbonyl bound to a novel $\mathrm{N}_{2} \mathrm{O}_{2}$ Schiff base. J. Mol. Struct.2010, 979, 77-85. https://doi.org/10.1016/j.molstruc.2010.06.004.

37. Chakravarthy, R.D.; Suresh, K.; Ramkumar, V.; Chand, D.K. New chiral molybdenum complex catalyzed sulfide oxidation with hydrogen peroxide. Inorg. Chim. Acta 2011, 376, 57-63. https://doi.org/10.1016/j.ica.2011.05.033. 
38. Rayati, S.; Rafiee, N.; Wojtczak, A. cis-Dioxo-molybdenum(VI) Schiff base complexes: Synthesis, crystal structure and catalytic performance for homogeneous oxidation of olefins. Inorg. Chim. Acta 2012, 386, 2735. https://doi.org/10.1016/j.ica.2012.02.005.

39. Rao, D.P. A review on versatile applications of novel Schiff bases and their metal complexes. Lett. Appl. NanoBioScience2019, 8, 675-681. https://doi.org/10.33263/LIANBS84.675681.

40. Pushie, M.J.; George, G.N. Spectroscopic studies of molybdenum and tungsten enzymes. Coord. Chem. Rev. 2011, 255, 1055-1084. https://doi.org/10.1016/j.ccr.2011.01.056.

41. Gautam, R.K.; Singh, C.P.; Prasad S.P.; Saxena, R.; Rao, D.P. Synthesis and antibacterial activity of novel molybdenum complexes with macrocyclic Schiff base derived from furanylethanedione. Asian J. Chem. 2019, 31, 2607-2612. https://doi.org/10.14233/ajchem.2019.22242.

42. Rao, C.P.; Sreedhara, A.; Rao, P.V.; Verghese, M.B.; Rissanen, K.; Kolehmainen, E.; Lokanath, N.K.; Sridhar, M.A.; Prasad, J.S. Syntheses, structure, reactivity and species recognition studies of oxovanadium(V) and molybdenum(VI) complexes. J. Chem. Soc. 1998, 14, 2383-2394. https://doi.org/10.1039/A801226A.

43. Hahn, R.; Herrmann, W.A.; Artens, G.R.J. Kleine, M. Biologically relevant metal coordination compounds: $\mathrm{Mo}^{\mathrm{VI}} \mathrm{O}_{2}$ and nickel(II) complexes with tridentate aromatic Schiff bases. Polyhedron 1995, 14, 2953-2960. https://doi.org/10.1016/0277-5387(95)00133-D.

44. Mendel, R.R. Molybdenum: biological activity and metabolism. Dalton Trans. 2005, 21, 3404-3409. https://doi.org/10.1039/B505527J.

45. Sigel, A.; Sigel, H. Metal Ions in Biological Systems, Molybdenum and Tungsten: Their Roles in Biological Processes, Marcel Dekker: NY, 2002, 39.

46. Maurya, R.C.; Shukla, B.; Pandey, A. Synthesis, magnetic and spectral studies of some cisdioxomolybdenum(VI) complexes derived from $\mathrm{N}$, O- and $\mathrm{N}_{2} \mathrm{O}_{2}$ - type Schiff bases. Indian J. Chem. 2002, 41A, 554-559. http://nopr.niscair.res.in/handle/123456789/29016.

47. Rousso, I.; Friedman, N.; Sheves, M.; Ottolenghi, M. pKa of the protonated Schiff base and aspartic 85 in the bacteriorhodopsin binding site is controlled by a specific geometry between the two residues. Biochemistry 1995, 34, 12059-12065. https://doi.org/10.1021/bi00037a049.

48. Bassov, T.; Sheves, M. Alteration of $\mathrm{pKa}$ of the bacteriorhodopsin protonated Schiff base. A study with model compounds. Biochemistry 1980, 25, 5249-5258. https://doi.org/10.1021/bi00366a040.

49. Mimoum, H.; Roch, I.S.D.; Sajus, L. Epoxydation des olefines par les complexes peroxydiquescovalents du molybdene-VI. Tetrahedron 1970, 26, 37-50. https://doi.org/10.1016/0040-4020(70)85005-0.

50. Conte, V.; Furia, F.D. Catalytic oxidations with hydrogen peroxide as oxidant, Kluwer Academic Publisher: Berlin, 1992.

51. Mimoum, H.; Saussine, L.; Daire, E.; Postel, M.; Fisher, J.; Weiss, R. Vanadium(V) peroxy complexes. New versatile biomimetic reagents for epoxidation of olefins and hydroxylation of alkanes and aromatic hydrocarbons. J. Am. Chem. Soc. 1983, 105, 3101-3110. https://doi.org/10.1021/ja00348a025.

52. Nair, M.L.H.; Thankamani, D. Synthesis and characterization of oxomolybdenum (V) and dioxomolybdenum (VI) complexes with schiff base derived from isonicotinoylhydrazide. Indian J. Chem. 2009, 48A, 1212-1218. http://nopr.niscair.res.in/handle/123456789/6010.

53. Garner, G.D. Molybdenum, special topics in Comprehensive Coordination Chemistry, Wilkinson G, Ed.; Pergamon press: Oxford, 1987, 6,1421.

54. Niasari, M.S.; Davar, F.; Bazarganipour, M. Synthesis, characterization and catalytic oxidation of para-xylene by a manganese(III) Schiff base complex on functionalized multi-wall carbon nanotubes (MWNTs). Dalton Trans. 2010, 39, 7330-7337. https://doi.org/10.1039/B923416K.

55. Ambroziak, K.; Beleck, R.M.; He, Y.; Saha, B.; Sherrington, D.C. Investigation of batch alkene epoxidations catalyzed by polymer-supported Mo(VI) complexes. Ind. Eng. Chem. Res. 2009,48, 3293-3302. https://doi.org/10.1021/ie801171s.

56. Vogel, A.I. A Text book of quantitative Inorganic analysis $4^{\text {th }}$ ed.; Longmans Green Co. Ltd., London, 1978.

57. Vogel, A.I. A Text book of practical organic chemistry $4^{\text {th }}$ ed.; Longmans Green Co. Ltd.: London, 1978.

58. Simmons, A. Practical medical microbiology $14^{\text {th }}$ ed.; Churchill Livingston: Edinberg, 11, 163, 1996.

59. Collee, J.G..; Duguid, J.P.; Frase, A.G.; Marmion, B.D. Practical medical microbiology, Churchill Livingstone: New York, 1989.

60. Nag, P.; Sharma, D. Synthesis, characterization and anticandidal activity of dioxomolybdenum(VI) complexes of the type $\left[\mathrm{MoO}_{2}\left\{\mathrm{ON}=\mathrm{C}\left(\mathrm{CH}_{3}\right) \mathrm{Ar}\right\}_{2}\right]$ and $\left[\mathrm{MoO}_{2}\left\{\mathrm{OC}(\mathrm{R}) \mathrm{CHC}\left(\mathrm{R}^{\prime}\right)=\mathrm{N}_{\mathrm{C}} 6 \mathrm{H}_{5}\right\}_{2}\right]$. Heliyon 2019, 5 , E01729. https://doi.org/10.1016/j.heliyon.2019.e01729. 
61. Rana, V.B.; Singh, P.; Singh, D.P.; Teotia, M.P.Trivalent chromium, manganese, iron and cobalt chelates of a tetradentate $\mathrm{N}_{6}$ macrocyclie ligand. Transit. Met. Chem. 1982, 7, 174-177. https://doi.org/10.1007/BF01035836.

62. Chandra, S.; Sharma, K.K. Synthesis and characterization of copper(II) complexes of a macrocyclic ligand. Transit. Met. Chem. 1983, 8, 1-3. https://doi.org/10.1007/BF00618784.

63. Malik, W.U.; Bembi, R.; Singh, R. Preparation and characterisation of some new 12- and 14-membered dibenzotetraaza macrocyclic complexes of iron(III). Inorg. Chim. Acta 1983, 68, 223-228. https://doi.org/10.1016/S0020-1693(00)88965-3.

64. Głowiak, T.; Jerzykiewicz, L.; Sobczak, J.M.; Ziółkowski, J.J. New insights into the chemistry of oxomolybdenum(VI) complexes with N-salicylidene-2-aminoethanol. Inorg. Chim. Acta 2003, 356, 387-392. https://doi.org/10.1016/S0020-1693(03)00301-3.

65. Ferraro, J.R. Low frequency vibrations of inorganic and coordination compounds. Plenum, New York, 1971.

66. Dyer, J.R. Applications of absorption spectroscopy of organic compounds. Prentice-Hall, Inc., Englewood Cliffs, NJ, 1965.

67. Singh, S.; Yadav, H.S.; Yadava, A.K.; Rao, D.P. Synthesis and characterization of oxovanadium(IV) complexes with tetradentate Schiff base ligands having thenil as precursor molecule. Curr. Res. Chem. 2011, 3, 106-113. https://doi.org/10.3923/crc.2011.106.113.

68. Willis, L.J.; Loehr, T.M.; Miller, K.F.; Bruce, A.E.; Stiefel, E.I. Raman and infrared spectroscopic studies of dioxomolybdenum(VI) complexes with cysteamine chelates. Inorg. Chem. 1986, 25, 4289-4293. https://doi.org/10.1021/ic00243a045.

69. Ceylan, B.I.; Kurt, Y.D.; Ulkuseven, B. Synthesis and characterization of new dioxomolybdenum(VI) complexes derived from benzophenone-thiosemicarbazone $\left(\mathrm{H}_{2} \mathrm{~L}\right)$. Crystal structure of $\left[\mathrm{MoO}_{2} \mathrm{~L}(\mathrm{PrOH})\right] . J$. Coord. Chem. 2009, 62, 757-766. https://doi.org/10.1080/00958970802339669.

70. Rao, S.N.; Munshi, K.N.; Rao, N.N.; Bhadbhade, M.M.; Suresh, E. Synthesis, spectral and X-ray structural characterization of [cis- $\left.\mathrm{MoO}_{2}(\mathrm{~L})(\mathrm{solv})\right](\mathrm{L}=$ salicylidenesalicyloyl hydrazine) and its use as catalytic oxidant. Polyhedron 1999, 18, 2491-2497. https://doi.org/10.1016/S0277-5387(99)00139-4.

71. El-Medani, S.M.; Aboaly, M.M.; Abdalla, H.H.; Ramadan, R.M. Reactions of group 6 metal carbonyls with salicylaldehyde hydrazone. Spectrosc. Lett. 2004, 37, 619-632.https://doi.org/10.1081/SL-200037610.

72. Zhu, X.W. Synthesis, crystal structures and catalytic property of dioxomolybdenum(VI) complexes derived from tridentate Schiff bases. Acta Chim. Slov. 2018, 65, 939-945. https://doi.org/10.17344/acsi.2018.4607.

73. Maurya, R.C.; Chourasia, J.; Martin, M.H.; Roy, S.; Sharma, A.K.; Vishwakarma, P. Dioxomolybdenum(VI) chelates of bioinorganic, catalytic, and medicinal relevance: Studies on some cis-dioxomolybdenum(VI) complexes involving O, N-donor 4-oximino-2-pyrazoline-5-one derivatives. Arabian J. Chem. 2015, 8, 293306. https://doi.org/10.1016/j.arabjc.2011.01.010.

74. Wang, X.; Zhang, X.M.; Liu, H.X. Synthesis, characterization and crystal structure of cisdioxomolybdenum(VI) complexes of the Schiff base Girard reagent (T) salt. J. Coord. Chem. 1994, 33, 223228. https://doi.org/10.1080/00958979408024280.

75. Mahmoudi, H.; Bagherzadeh, M.; Ataie, S.; Kia, R.; Heydar Moravej, S.; Zare, M.; Raithby, P.R.; Ferlin, F.; Vaccaro, L. Synthesis and X-ray crystal structure of a Molybdenum(VI) Schiff base complex: Design of a new catalytic system for sustainable olefin epoxidation. Inorg. Chim. Acta 2020, 511, 119775. https://doi.org/10.1016/j.ica.2020.119775.

76. Rao, D.P.; Yadav, H.S.; Yadava, A.K.; Singh, S.; Yadav, U.S. Syntheses and spectroscopic studies on macrocyclic complexes of dioxomolybdenum(VI) with furil as precursor. E-J. Chem. 2012, 9, 497503.https://doi.org/10.1155/2012/205123.

77. Cotton, F.A.; Wilkinson, G.; Murillo, C.A.; Bochmann, M. Advanced Inorganic Chemistry. $6^{\text {th }}$ ed., Wiley, New York, 1999,18, 944-947.

78. Nakamoto, K. Infrared and Raman Spectra of inorganic and coordination compounds. New York: Wiley, 1978. https://doi.org/10.1002/0470027320.s4104.

79. Gehrke, H.; Veal, J. Acetylacetonate complexes of molybdenum(V) and molybdenum(VI). Inorg. Chim. Acta 1969, 3, 623-627. https://doi.org/10.1016/S0020-1693(00)92563-5.

80. Yadav, H.S. Synthesis of spectroscopic studies of oxovanadium(IV) complexes with 16- and 18-membered macrocyclic ligands. Polyhedron 1993, 12, 313-317.https://doi.org/10.1016/S0277-5387(00)81729-5.

81. Rao, D.P.; Yadav, H.S.; Yadava, A.K.; Singh, S.; Yadav, U.S. In-situ preparation of macrocyclic complexes of dioxomolybdenum(VI) involving a heterocyclic precursor. J. Coord. Chem. 2011, 64, 293-299. https://doi.org/10.1080/00958972.2010.544037. 
82. Sakata, K.; Kuroda, M.; Yanagida, S.; Hashimoto, M. Preparation and spectroscopic properties of oxovanadium(IV) and dioxomolybdenum(VI) complexes with tetraaza[14] annulenes containing pyridine rings. Inorg. Chim. Acta 1989, 156, 107-112. https://doi.org/10.1016/S0020-1693(00)90375-X.

83. Gautam, R.K.; Singh, C.P.; Kumar, D.; Rao, D.P. New Insights into the Chemistry of cisDioxomolybdenum(VI) Schiff base complexes with macrocyclic ligands. Chem. Sci. Trans. 2019, 8, 467476. https://doi.org/10.7598/cst2019.1594.

84. Garg, R.; Saini, M.K.; Fahmi, N.; Singh, R.V. Spectroscopic and biochemical studies of some manganese(II), oxovanadium(V) and dioxovanadium(VI) complexes $\mathrm{S} / \mathrm{O}$ and $\mathrm{N}$ donor agents synthesized under microwave conditions. Transit. Met. Chem. 2006, 31, 362-367. https://doi.org/10.1007/s11243-005-0001-1.

85. Gautam, R.K.; Singh, C.P.; Saxena, R.; Rao, D.P. Synthesis and studies of some cis- $\mathrm{MoO}_{2}$ (VI) complexes with nitrogen donor macrocyclic ligands. Eur. Chem. Bull. 2019, 8, 387-393. https://doi.org/10.17628/ecb.2019.8.387-393.

86. Kahroic, E.; Molcanov, K.; Tusek-Bozic, L.; Kojic-Prodic, B. New complexes of Mo(V) with Schiff bases: Crystal structure of butylammonium di- $\mu$-oxo- $\mu$-acetato-bis[(N-butylsalicylideniminatoN,O)oxomolybdenum(V)] benzene, acetic acid solvate. Polyhedron 2006, 25, 2459-2464. https://doi.org/10.1016/j.poly.2006.02.008.

87. Ballhausen, C.J.; Gray, H.B. The electronic structure of the vanadyl ion. Inorg. Chem. 1962, 1, 111-122. https://doi.org/10.1021/ic50001a022. 